Banco, Volume 1, Mei 2019

\title{
KOMPARASI PELAKSANAAN TAKE OVER PADA BANK NEGARA INDONESIA SYARIAH DAN BANK RAKYAT INDONESIA DI PAREPARE
}

\author{
Zulfhaidz Husain \\ IAIN Parepare \\ zulfhaidshusain@gmail.com \\ Muhammad Kamal Zubair \\ IAIN Parepare \\ muhammadkamalzubair@iainpare.ac.id \\ Damirah \\ IAIN Parepare \\ Damirah@iainpare.ac.id
}

\begin{abstract}
Take Over is an action carried out by users of banking services to move payments or installments that are considered more profitable by users of banking services, where in this case the Customer, the transfer made in the form of transfer of services, payments and installments that customers consider more profitable for them Use. The transfer of payment its elf involves two different banking institutions where installments or financing that run from one bank to another are transferred according to the provisions of each banking institution involved in it. The results of this study indicate that there are several differences in take-over systems implemented by Bank Negara Indonesia Syariah and Bank Rakyat Indonesia, including the contract agreement system that exists in these two banking institutions, where Bank Negara Indonesia Syariah uses a system with a sharia contract, namely the contract is a profit sharing contract, which they apply is a Murabahah contract and guidelines for the rules and procedures carried out at Take Over are the foundation of the DSNMUI Fatwa and all provisions contained in the land, then at the Bank Rakyat Indonesia the contract used is in accordance with the provisions of the party banking itself the interest rate applied to the Contract is a Flat (fixed and Floating) interest rate or a fixed interest rate with the provisions of the installment table in accordance with the provisions of the Bank Rakyat Indonesia.
\end{abstract}

Keywords: Take Over, Bank Syariah, Comparison 


\begin{abstract}
Abstrak
Take Over merupakan suatu tindakan yang dilakukan oleh pengguna jasa perbankan guna memindahkan pembayaran atau angsuran yang dianggap lebih menguntungkan oleh pengguna jasa perbankan, dimana dalam hal ini adalah Nasabah, pemidahan yang dilakukan berupa pemindahan jasa, pembyararan, serta angsuran yang nasabah anggap lebih menguntungkan untuk mereka gunakan. Pemindahan pembyaran itu sendiri melibatkan dua lembaga perbankan yang berbeda dimana angsuran atau pembiyaan yang berjalan dari bank satu ke bank lainnya dipindah alihkan sesuai dengan ketentuan masing-masing lembaga perbankan yang terlibat didalamnya. Hasil dari penelitian ini menunjukkan terdapat beberapa perbedaan sistem take over yang dilaksanakan oleh Bank Negara Indonesia Syariah dan Bank Rakyat Indonesia, diantaranya adalah sistem akad perjanjian yang ada pada kedua lembaga perbankan ini, dimana Bank Negara Indonesia Syariah menggunakan sistem dengan akad syariah yaitu pada akad tersebut adalah akad bagi hasil, yang mereka terapkan adalah akad Murabahah serta pedoman untuk aturan dan prosedur yang dijalankan pada saat Take Over adalah landasan dari Fatwa DSN-MUI serta segala ketentuan yang terdapat didlamnya, kemudia pada Bank Rakyat Indonesa akad yang digunakan adalah sesuai dengan ketentuan pihak perbankan itu sendiri suku bunga yang diterapkan pada Akad adalah suku bunga Flat (fixed and Floating) Atau suku bungan tetap dengan ketentuan tabel angsuran sesuai dengan ketetapan pihak Bank Rakyat Indonesia.
\end{abstract}

Kata Kunci: Take Over, Bank Syariah, Komparasi

\title{
A. Pendahuluan
}

Lalu lintas keuangan di Indonesia semakin berkembang dengan berkembangnya zaman, sistem keuangan yang dulunya menggunakan metode standar kini semakin berkembang dengan adanya sistem terpadu, terutama diperbankan yang dimana pengertian perbankan adalah lembaga keuangan yang menghimpun dana dari masyarakat dalam bentuk simpanan dan menyalurkan dana kepada masyarakat dalam bentuk pinjaman ${ }^{1}$. Sedangkan perbankan di Indonesia terbagi menjadi dua sistem yakni sistem perbankan yang selama ini kita kenal secara umum yaitu sistim konvensional dan sistem perbankan yang berbasis Islam yaitu perbankan syariah yang dimana bank syariah merupakan bank yang menjalankan kegiatan usahanya berdasarkan prinsip-prinsip Syariah ${ }^{2}$.

Krisis ekonomi yang terjadi pada tahun 1997 menunjukan bahwa bank yang beroperasi dengan prinsip syariah relatif dapat bertahan dan memiliki kinerja lebih baik di tengah gejolak nilai tukar dan tingkat suku bunga yang tinggi. Hal ini terjadi pada angka NPFs (Non-performing Financings) yang lebih rendah dibandingkan dengan sistem konvensional dalam menjalankan fungsi Intermediasi. Karena dalam Perbankan Syariah melarang adanya bunga (riba), transaksi yang bersifat tidak transparan (gharar), dan spekulatif (maysir) $)^{3}$

Dalam perbankan di Indonesia segala bentuk aktifitas kerja keuangan perbankan diatur dan dipantau langsung oleh BI (Bank Indonesia) yang dimana BI menjadi regulator perbankan di Indonesia termasuk juga bank-bank syariah untuk semua kegiatan serta pelaporan dan pengawasannya. Segala bentuk dari kegiatan transakasi dalam perbankan syariah berdasarkan fatwa yang dikeluarkan oleh lembaga yang memiliki kewenanagan dalam penetapan fatwa dibidang syariah yang di Indonesia yang disebut Dewan

${ }^{1}$ Ahmad Zainal, Mengenal Lembaga Keungan Bank dan Non Bank (Jakarta:Akasara Pertama Pena, 2013), h. 34.

${ }^{2}$ Kautsar Riza Salman, Akuntansi Perbankan Syariab: Berbasis PS AK Syariah(Jakarta: Akademia Pertama, 2014), h.

69.

${ }^{3}$ Andrian Sutedi, Perbankan Syariah(Bogor: Ghalia Indonesia, 2009), h. 42. 
Syariah Nasional (DSN) yakni, dewan yang dibentuk oleh Majelis Ulama Indonesia (MUI) dengan tugas dan wewenang antara lain, mengeluarkan fatwa atas jenis-jenis kegiatan keuangan serta produk-produk dan jasa keuangan syariah ${ }^{4}$. Melihat adanya perbedaan karakteristik antara bisnis keuangan syariah dan konvensioanal maka persaingan dalam pemasaran produk-produknya juga semakain ramai. Salah satu kemudahan yang ditawarkan dalam bisnis perbankan yakni adanya pemindahan pembayaran yang bisa dilakukan antara sesama bank dengan menggunakan sistem pembayaran dan transaksi sesuai dengan bank yang telah dipindahkan tersebut, hal ini disebut take over (sitem take over)

Istilah ini di dunia bisnis perbankan dinamakan dengan istilah take over. Take over merupakan suatu istilah yang dipakai dalam dunia perbankan dalam hal ini pihak ketiga memberi kredit kepada debitur yang bertujuan untuk melunasi hutang/kredit kepada kreditur awal dan memberikan kredit baru kepada debitur sehingga kedudukan pihak ketiga ini menggantikan kedudukan kreditur awal, peristiwa peralihan hutang ini identik dengan peristiwa SUBROGASI sesuai pasal 1400 KUHPerdata. Yang menyatakan bahwa subrogasi adalah pemindahan hak kreditur kepada seorang pihak ketiga yang membayar kepada kreditur dapat terjadi karena persetujuan atau kerena undang-undang. Subrogasi ini bisa dilakukan baik secara langsung maupun tidak langsung ${ }^{6}$

Dalam praktek pelaksanaannya sendiri take over digunakan nasabah sebagai alterantif pemindahan pembiayaan dan kredit angsuran. Dengan adanya take over nasabah dapat memindahkan angsuran pembayaran suatu barang ke bank yang diinginkan sesuai dengan spesifikasi bank berjalan, yang dimana dinilai lebih menguntungkan dan mampu menawarkan suatu keuntugan untuk nasabah. Take over ini juga membuka peluang untuk perbankan melakukan persaingan secara luas dengan bank lainnya karena adanya persaingan dalam pembayaran dan fitur-fitur yang dianggap dapat dipasarkan dan bertujuan mendorong nasabah bank lain untuk melakukan pemindahan pembayaran atau take over ke bank yang lebih mampu memberi keuntungan.

Dalam memasarkan produknya masing-masing lembaga perbankan mempunyai strategi yang berbeda untuk mendapatkan nasabah baru atau untuk lebih memberikan pelayanan terbaik kepada nasabahnya masing-masing maka dari itu penelitian ini akan membandingka sisitem take over pada dua lembaga perbakan yakni PT. BNI Syariah KCP Parepare dan PT. BRI KCP Parepare.

\section{B. Dikusi dan Pembahasan}

\section{Standar Operational (SOP) Pelaksanaa dan Penerapan Sistem Take Over pada BNI syariah Mikro KC Parepare}

Take over adalah suatu proses yang dilakukan guna menmindahkan suatu pembayaran antar bank, dimana dalam prosesnya take Over akan memindahkan seluruh aktivitas pembayaran surat berharga, serta jumlah angsuran yang harus dilakukan nasabah ,pada BNI Syariah KC Mikro Parepare take over belum terlalu banyak dilakukan dikarena bank Syariah KC Mikro Parepare termasuk pendatang baru di kota Parepare tetapi proses take over kerap digunakan apabila nasabah

${ }^{4}$ Veithzal Rivai Dan Arviyan Arifin, Islamic Banking: Sebuah Teori, Konsep, Dan Aplikasi (Jakarta, PT Bumi Aksara, 2010), h. 375.

5Rizal Yaya, Moderenisasijasa perbankan Indonesia Teori Dan Praktik Kontenporer (Jakarta: Salemba Empat, 2012), h. 80.

${ }^{6}$ Liesti Yowati, Indahnya Belajar Akuntansi, (Akuntan-si.si.blogspot.co.id/2013/definisi-dan-mekanisme-takeover.hmtl?m=1). 
ingin memindahka pembayarannya ke bank BNI Syariah KC Mikro Parepare ataupun sebaliknya nasabah ingin men-take over pembiyaanya dari bank Syariah KC Mikro Parepare ke bank yang akan dilakukan take over. Dalam prosesnya take over pada bank ini memberikan kemudahan pada nasabah dalam proses pembayaran dikarenakan pemindahan pembayaran atau take over menungkinkan nasabah untuk memilah bank yang dimana keunggulan yang ditawarkan oleh pihak pembiyaan dalam hal ini adalah lembaga perbankan yang bersangkutan dianggap lebih memberi keuntungan pada nasabah.

Sebagai awal dari sistem pembiayaan take over, calon nasabah pembiayaan take over sebelum mengajukan permohonan pembiayaan terlebih dahulu berkonsultasi dengan pihak PT. BNI Syariah. Konsultasi ini dimaksudkan untuk mencari informasi mengenai pembiayaan take over, baik berupa bagaimana sistem, syarat, maupun margin keuntungan yang diambil oleh BNI Syariah. Jika calon nasabah tersebut tertarik dengan informasi yang diberikan oleh pihak PT. BNI Syariah, maka persiapan selanjutnya yang perlu dilakukan oleh calon nasabah pembiayaan take over yaitu menginformasikan kepada bank yang sebelumnya yakni bank konvensional bahwa kredit rumah yang sudah berjalan pada bank konvensional tersebut akan di take over-kan ke bank syariah. Biasanya pihak bank sebelumnya tidak begitu saja melepaskan nasabahnya, karena hal ini tentu saja akan berpengaruh pada perolehan keuntungan dari sisi aktiva produktifnya. Namun demikian, keputusan tetap ada di tangan nasabah.

Langkah untuk mengajukan permohonan pembiayaann take over, yaitu sebagai berikut:

a. Persiapan sebelum ke bank

b. Dokumen-dokumen yang perlu disiapkan nasabah sebelum mendatangi PT. BNI Syariah antara lain bisa diliat pada tabel dibawah ini :

Tabel Persyaratan Dokumen Take Over Bank BNI Syariah KC Mikro Parepre

\begin{tabular}{|c|c|c|c|c|}
\hline $\mathrm{NO}$ & DOKUMEN & PEGAWAI & PENGUSAHA & PROFESIOANAL \\
\hline 1 & $\begin{array}{l}\text { Fotocopy KTP/Paspor } \\
\text { pemohon suami/istri }\end{array}$ & $\sqrt{ }$ & $\sqrt{ }$ & $\sqrt{ }$ \\
\hline 2 & $\begin{array}{l}\text { Pasfoto } 3 \times x \quad 4 \text { pemohon } \\
\text { suami/istri }\end{array}$ & $\sqrt{ }$ & $\sqrt{ }$ & \\
\hline 3 & $\begin{array}{l}\text { Fotocopy surat nikah / } \\
\text { cerai / pisah harta (jika } \\
\text { pisah harta) }\end{array}$ & $\sqrt{ }$ & $\sqrt{ }$ & \\
\hline 4 & Fotocopy kartu keluarga & $\sqrt{ }$ & $\sqrt{ }$ & \\
\hline 5 & $\begin{array}{l}\text { Fotocopy surat WNI, surat } \\
\text { keterangan ganti nama bagi } \\
\text { WNI keturunan }\end{array}$ & $\sqrt{ }$ & $\sqrt{ }$ & \\
\hline 6 & $\begin{array}{l}\text { Fotocopy NPWP (untuk } \\
\text { pembiayaan di atas Rp. } 50 \\
\text { juta) }\end{array}$ & $\sqrt{ }$ & $\sqrt{ }$ & \\
\hline 7 & $\begin{array}{l}\text { Fotocopy rekening koran / } \\
\text { tabungan } \\
3 \text { bulan terakhir }\end{array}$ & $\sqrt{ }$ & $\sqrt{ }$ & \\
\hline
\end{tabular}




\begin{tabular}{|c|c|c|c|c|}
\hline 8 & $\begin{array}{l}\text { Asli slip gaji terakhir / } \\
\text { surat keterangan } \\
\text { penghasilan }\end{array}$ & $\sqrt{ }$ & & \\
\hline 9 & $\begin{array}{l}\text { Asli surat keterangan masa } \\
\text { kerja dan jabatan terakhir } \\
\text { dari perusahaan }\end{array}$ & $\sqrt{ }$ & & \\
\hline 10 & $\begin{array}{l}\text { SK pengangkatan awal } \\
\text { pegawai dan SK terakhir }\end{array}$ & $\sqrt{ }$ & & \\
\hline 11 & SPT pajak 1 tahun terakhir & $\sqrt{ }$ & $\sqrt{ }$ & $\sqrt{ }$ \\
\hline 12 & $\begin{array}{l}\text { Neraca dan laba rugi / } \\
\text { informasi keuangan } 2 \\
\text { tahun terakhir }\end{array}$ & & $\sqrt{ }$ & $\sqrt{ }$ \\
\hline 13 & $\begin{array}{l}\text { Akte perusahaan, SIUP } \\
\text { dan TDP }\end{array}$ & & $\sqrt{ }$ & \\
\hline 14 & Fotocopy surat izin profesi & & & $\sqrt{ }$ \\
\hline 15 & $\begin{array}{ll}\text { Dokumen kepemilikan } \\
\text { jaminan : } \\
\checkmark & \text { Fotocopy sertifikat dan } \\
& \text { IMB } \\
\checkmark & \text { Surat pesanan / } \\
& \text { penawaran } \\
\checkmark & \text { Fotocopy bukti setoran } \\
& \text { PBB terakhir } \\
\checkmark & \text { Rencana anggaran } \\
& \text { biaya (RAB) }\end{array}$ & $\sqrt{ }$ & $\sqrt{ }$ & $\sqrt{ }$ \\
\hline 16 & $\begin{array}{l}\text { Denah lokasi jaminan dan } \\
\text { rumah tinggal }\end{array}$ & $\sqrt{ }$ & $\sqrt{ }$ & $\sqrt{ }$ \\
\hline
\end{tabular}

Sumber Brosur BNI iB Griya

c. Mengisi Aplikasi Permohonan Pembiayaan Calon Nasabah

Dibawah bimbingan petugas atau karyawan BNI Syariah mengisi aplikasi permohonan pembiayaan. Aplikasi tersebut pada umumnya berisi tentang data pribadi, data pekerjaan, data suami istri, data penghasilan, pembiayaan / pinjaman lain, data kekayaan, data simpanan rekening di bank dan data agunan. Setelah aplikasi diisi dan ditandatangani oleh calon nasabah, kemudian diserahkan kembali kepada petugas bank dan petugas bank yang akan melakukan berbagai analisa atas permohonan pembiayaan tersebut.

d. Analisa Pejabat PT BNI Syariah

Sebagai awal dari tahap analisa, petugas bank melakukan wawancara untukmencari kebenaran data di dalam aplikasi permohonan pembiayaan. Selanjutnya dilakukan pemeriksaan ke tempat calon nasabah untuk meneliti secara fisik kebenaran data 
permohonan pembiayaan, pemeriksaan ini disebut dengan istilah On the Spot (OTS). Dari hasil OTS kemudian dilakukan analisa pembiayaan. Pada PT BNI Syariah Mikro KC Parepare digunakan metode analisa $5 \mathrm{C}$, yaitu:

1) Character (Karakter)

Analisa ini merupakan analisa kualitatif yang tidak dapat dideteksi secara numerik. Analisa ini dapat dilakukan dengan hal-hal berikut:

a) Wawancara gunanya untuk mencari kebenaran data di dalam aplikasi permohonan pembiayaan.

b) BI checking dilakukan untuk mengetahui riwayat pembiayaan yang telah diterima oleh nasabah berikut status nasabah yang yang ditetapkan oleh BI. Tunggakan pinjaman nasabah di bank lain juga memberikan indikasi yang buruk terhadap karakter nasabah.

2) Capacity (Kapasitas / kemampuan)

Kapasitas calon nasabah sangat penting diketahui untuk memahami kemampuan seseorang untuk berbisnis. Untuk pembiayaan konsumtif, analisa diarahkan pada kemampuan sumber penghasila calon nasabah membiayai seluruh pengeluaran bulanannya. Yang perlu dianalisa adalah:

a) perusahaan tempat yang bersangkutan bekerja

b)lama bekerja dan penghasilan.

3) Capital (Modal)

Analisa modal diarahkan untuk mengetahui seberapa besar tingkat keyakinan calon nasabah terhadap usahanya sendiri. Jika nasabah sendiri tidak yakin akan usahanya, maka orang lain akan lebih tidak yakin.

4) Condition (Kondisi)

Kondisi yang harus diperhatikan bank antara lain :

a) Keadaan ekonomi yang akan mempengaruhi perkembangan usaha calon nasabah

b) Kondisi usaha calon nasabah

c) Keadaan pemasaran dari hasil usaha calon nasabah

d) Prospek usaha dimasa yang akan datang

e) Kebijakan pemerintah yang akan mempengaruhi prospek

f) Industry dimana perusahaan calon nasabah terkait didalamnya

5) Collateral (Jaminan)

Analisa ini diarahkan terhadap jaminan yang diberikan. Jaminan yang dimaksud harus mampu meng-cover bisnis calon nasabah analisa yang dilakukan antara lain:

a) Meneliti kepemilikan jaminan yang diserahkan

b) Mengukur dan memperkirakan stabilitas harga jaminan dimaksud

c) Memperhatikan kemampuan untuk dijadikan uang dalam waktu relatif singkat tanpa harus mengurangi nilainya

d) Memperhatikan pengikatannya sehingga secara legal bank dapat dilindungi

e) Rasio jaminan terhadap jumlah pembiayaan.

f) Marketabilitas Jaminan.

e. Persetujuan atau Penolakan Pembiayaan

Setelah melakukan analisa-analisa tersebut di atas,bank akan menyetujui atau menolak permohonan pembiayaan calon debitur, jika bank menyetujuinya, maka pihak bank akan menginformasiakan kepada calon debitur.

f. Pengikatan / Perjanjian Pembiayaan 
Calon debitur akan dipanggil oleh pihak bank, kemudian dialkukan kembali pernyataan lisan pada nasabah yabg akan melakukan take over, jika nasabah setuju dengan persyaratan yang termuat dalam akad tertulis oleh pihak bank, maka akan dilanjutkan dengan pengikatan pembiayaan dan agunan.

g. Pencairan Pembiayaan

Setelah dilakukan, kemudian pengikatan/ perjanjian pembiayaan, selanjutnya adalah pencairan dana. Pencairan dana ini dilakukan melalui rekening nasabah, jika nasabah belum mempunyai rekening pada BNI Syariah, maka nasabah diharuskan membuka rekening terlebih dahulu agar dapat tercatat sebagai nasabah di BNI syariah dan mempunyai aktifitas rekening yang nantinya aktifitas rekening tersebut yang akan tercantum dan tercatat sebagai rekening koran nasabah. Didalam rekening yang telah dibuka tersebut apabila nasabah hanya ingin menggunakan jasa bank BRI hanya sekedar perantara pembayaran maka saldo minimun rekeneing adalah sesuai dengan ketentuan bank BRI yaitu Rp.50.000.

h. Monitoring

Monitoring dapat dilakukan dengan memantau realisasi pencapaian target usaha dengan bisnis plan yang telah dibuat sebelumnya. Apabila terjadi tidak tercapainya target, maka officer bank harus segera melakukan tindakan penyelamatan.

Akad take over menggunakan skim pembiayaan murabahah sebagaimana dijelaskan dalam Fatwa Dewan Syariah Nasional Nomor 04/DSN-MUI/IV/2000 tentang murabahah. Ketentuannya sebagai berikut :

a. Ketentuan umum murabahah dalam bank syariah.

1) Akad murabahah bebas riba.

2) Barang yang diperjual belikan tidak diharamkan

3) Bank membiayai sebagian atau seluruh harga pembelian barang.

4) Bank membeli barang yang diperlukan nasabah atas nama bank sendiri, pembelian ini harus sah dan bebas riba. Barang tersebut harus terlebih dahulu dipindah namakan atas nama bank BNI syariah kemudian setelah bank memiliki hak pakai barang maka barulah dapat pindah akadkan ke nasabah dengan begitu barang tersebut dapat di-Take Over

5) Bank harus menyampaikan semua hal yang berkaitan dengan pembelian mulai dari harga barang itu sendiri, keuntungan yang diproleh bank atau margin keuntungan bank, kemudian harga atau angsuran yang harus dibayarkan oleh nasabah.

6) Bank menjual barang kepada nasabah pemesan dengan harga jual senilai harga beli plus keuntungannya yang akan tertuang pada klausul akad perjanjian yang nantinya disepakati oleh kedua pihak.

7) Nasabah membayar harga barang yang disepakati pada jangka waktu tertentu

8) Untuk mencegah penyalahgunaan atau kerusakan akad, bank dapat mengadakan perjanjian khusus dengan nasabah

9) Jika bank mewakilkan kepada nasabah untuk membeli barang dari pihak ketiga, akad jual beli murabahah harus dilakukan setelah barang secara prinsip menjadi milik bank. ${ }^{8}$

${ }^{8}$ Fatwa DSN Nomor : 04/DSN-MUI/IV / 2000 Tentang Murabahah 
b. Ketentuan murabahah kepada nasabah

1) Nasabah mengajukan permohonan dan perjanjian pembelian suatu barang atau asset kepada bank.

2) Jika bank menerima, ia harus membeli terlebih dahulu asset yang dipesannya secara sah dengan pedagang.

3) Bank menawarkan asset tersebut kepada nasabah dan nasabah harus menerima (membeli)-nya, karena secara hukum perjanjian tersebut mengikat, kemudian kedua belah pihak harus membuat kontrak jual beli.

4) Bank diperbolehkan meminta nasabah untuk membayar uang muka saat menendatangani kesepakatan awal pemesanan.

5) Jika nasabah menolak membeli barang, biaya riil bank harus dibayar dari uang muka tersebut.

6) Jika nilai uang muka kurang dari kerugian bank, bank dapat meminta kembali sisa kerugiannya kepada nasabah.

7) Jika uang muka memakai kontrak urbunsebagai alternatif dari uang muka, maka:

a) Jika nasabah membeli, ia tinggal membayar sisa harga,

b)Jika nasabah batal membeli, maka menjadi milik bank maksimal sebesar kerugian bank dan jika tidak mencukupi nasabah wajib melunasi kekurangannya.

c. Jaminan Murabahah

1) Jaminan dalam murabahah dibolehkan agar nasabah serius dengan pesanannya.

2) Bank dapat meminta nasabah untuk menyediakan jaminan yang dapat dipegang.

d. Ketentuan Murabahah

1) Secara prinsip, penyelesaian utang tidak ada kaitannya dengan transaksi lain. Jika nasabah menjual barang dengankeuntungan atau kerugian, ia tetap berkewajiban untuk menyelesaikan utangnya kepada bank.

2) Jika nasabah menjual barang:

a) Sebelummasa angsuran berakhir, ia tidak wajib segerah melunasi seluruhnya.

b) Menyebabkan kerugian, tetap harus menyelesaikan utangnya sesuai kesepakatan awal.

c) Tidak boleh memperlambat pembayaran angsuran atau meminta kerugian itu diperhitungkan.

3) Nasabah yang memiliki kemampuan tidak dibenarkan menunda penyelesaian utangnya.

4) Jika nasabah telah dinyatakan pailit dan gagal menyelesaiakn utangnya, bank harus menunda tagihan utang sampai ia sanggup kembali atau berdasarkan kesepakatan.

e. Ketentuan uang muka nasabah

1) Dalam akadmurabahah, LKS diperbolehkan untuk memita uang muka.

2) Besar uang muka ditentukan berdasarkan kesepakatan.

3) Jika nasabah membatalkan akad, nasabah harus memberikan ganti rugi kepada LKS dari uang muka tersebut.

4) Jika uang muka lebih kecil dari kerugian maka LKS dapat meminta tambahan kepada nasabah 
5) Jika uang muka lebih besar dari kerugian, maka LKS harus mengembalikan kelebihannya kepada nasabah

f. Ketentuan diskon murabahah

1) Harga jual beli adalah suatu jumlah yang disepakati oleh kedua belah pihak.

2) Harga jual beli murabahah adalah harga beli dan biaya yangdiperlukan ditambah keuntungan sesuai dengan kesepa katan.

3) Jika dalam murabahah LKS mendapat diskon dari supplier, maka diskon tersebut adalah hak nasabah.

4) Jika diskon setelah akad, maka pembagian diskon sesuai perjanjian persetujuan dalam akad.

5) Dalam akad, pembagian diskon setelah akad hendaklah diperjanjikan dan ditandatangani.

g. Ketentuan sanksi (denda)

1) Sanksi yang dikenakan kepada nasabah yang mampu membayar, tetapi menundanunda pembayaran dengan sengaja.

2) Nasabah yang tidak mampu disebabkan force majeur tidak boleh dikenakan sanksi.

3) Nasabah mampu yang menunda-nunda pembayaran dan atau tidak mempunyai kemauan baik itikad baik boleh dikenakan sanksi.

4) Sanksi bertujuan agar nasabah lebih disiplin dalam melaksanakan kewajibannya.

5) Sanksi dapat berupa denda sejumlah uang yang besarnya ditentukan atas dasar kesepakatan dan dibuat saat akad ditandatangani

6) Dana yang berasal dari denda diperuntukkan sebagai dana sosial.

\section{Standar Operational (SOP) Pelaksanaa dan Penerapan Sistim Take Over pada BRI KCP Parepare (Unit Hasanuddin)}

Pada dasarnya take over yang ditawarkan oleh bank BRI mengacu pada pelayan yang menjadi fasilitas utama dalam melakukan pemindahan pembayaran atau Take over pada Bank BRI, selain itu berbagai fasilitas tambahan yang ditawarkan pada nasabah menjadi daya tarik tersendiri yang salah satunya membuat nasabah ingin memindahkan pembayarannya atau men-Take over pembayarannya yang mereka anggap lebih menguntungkan bagi mereka, setelah nasabah ingin memidahkan pembayarannya pada Bank BRI terlebih dahulu nasabah melakukan konsultasi seputar take over atau pemindahan pembayaran yang akan nasabah tersebut lakukan hal ini guna menambah wawasan pada nasabah dan memberikan informasi pada nasabah seputar produk, tata cara dan beberapa fitur-fitur yang nntinya akan didapatkan ketika nantinya nasabah telah melakukan take over.

Dalam bebrapa program yang dilakukan BRI serta unit-unit yang tersebar diseluruh wilayah Indonesia BRI mempunyai cara tersendiri untuk menarik nasabahnya kemudian nasabah yang akan melakukan take over. Nasabah yang melakukan take over ini akan dipandu khusus oleh karyawan pada bidangnya sampai proses tersebut selsesai dilaksanakan, kemudian tetap dilakukan peninjauan dan monitoring oleh pihak BRI sebagai pelayan untuk nasabahnya, beberapa tawaran menarik juga diberikan oleh pihak BRI dimana hal tersebut akan lebih memudahkan proses take over dan tentunya ini yang akan menjadi salah satu penilaian serta tolak ukur ukur nasabah ketika ingin menggunakan produk serta jasa bank BRI. 
Ahmad Fauzi, sales KPR BRI, menuturkan, BRI memiliki dua skema take over KPR. Pertama, skema murni dimana bank mengucurkan plafon kredit sesuai dengan jumlah yang diberikan oleh bank asal. Kedua, skema top up. Jadi, besar pinjaman diberikan sesuai hasil appraisal agunan. Jika kredit disetujui, BRI akan melunasi sisa utang debitur di bank awal. Sisanya bisa digunakan oleh debitur untuk keperluannya. BRI menawarkan bunga tetap untuk KPR take over sebesar 8,75 persen selama dua tahun. Maksimal plafon pinjaman yang diberikan BRI adalah Rp 5 miliar. Untuk biaya, BRI mematok biaya administrasi 0,1 persen dan provisi 1 persen dari plafon kredit. "Total biaya tidak lebih dari 3 persen dari total utang,"9.

Adapun jenis-jenis Produk Take Over BRI KCP Parepare (Unit Hasanuddin) adalah sebagai berikut:

a. Take over pembiyaan kendaraan bermotor

Take over kendaraan bermotor adalah salah satu alternatif untuk nasabah yang hendak memindahkan angsuran kendaraan bermotor yang sedang mereka lakukan dimana proses tersebut telah berjalan kemudian nasabah ingin melaukan take over untuk mengganti jumlah angsuran ataupun tempat pembiayaan yang akan mereka gunakan. Pada BRI take over terdapat produk serupa yaitu " take over kendaraan bermotor BRI" tetapi produk ini masi jarang digunakan oleh bank BRI terutama pada bank BRI KCP Parepare,

b. Take over KPR

Take over KPR adalah produk yang banyak banyak terdapat take over di dalamya yang menjadi salah satu produk yang dimana produk tersebut sering diunggulakan Pada BRI KCP Parepare yang dimana pembiyaan KPR tersebut kebanyakan pembiyaan bersifat mikro dan ada pula beberapa yang mempunyai pembiyaan dengan jumlah menegah ke atas .Bank BRI melalui program KPR BRI memberikan layanan Kredit Pemilikan Rumah yang dananya dapat digunakan untuk pembiayaan pembangunan, pembelian, renovasi ataupun take over properti impian.

KPR BRI memberikan pembiayaan KPR hingga 90\% untuk pembelian baru/second, pembangunan, renovasi maupun take over kepemilikan properti dari bank lain. Dapatkan berbagai manfaat seperti suku bunga rendah dan perlindungan asuransi jiwa dan asuransi kerugian agunan. Jumlah angsuran yang berfariatif juga menjadi daya jual dalam melakukan take over khususnya take over KPR dengan tenor hingga 20 tahun nasabah bebas memperhitungkan dan memililh berapa nominal pembayaran yang akan mereka lakukan setiap tahunnya atau dapat juga dirincikan setiap bulannya. Untuk jangka waktu pencairan adalah 14 hari waktu kerja tetapi biasanya bisa lebih cepat tergantung dari kelengkapan dokukmen serta syarat-syarat yang diperlukan, kemudain pada saat masa pembekuan rekening sementara, yaitu pada saat proses take over pemindahan pembiyaan berlangsung nasabah tidak dapat melakukan aktifitas rekening banknya dikarenakan untuk menghindari transaksi-transaksi yang dapat mengganggu akrifitas pemindahan. Nasabah akan mendapatkan perlindungan secara menyeluruh pada saat write off berlangsung rekening nasabah akan dilindungi oleh pihak bank validasi serta kerahasiaan rekening koran nasabah dan transaksi nasabah sampai pemindahan selesai berlangsung.

9' Kompas, comhttps://properti.kompas.com/read/2014/01/31/1208428/Nih.Beberapa.Tawaran.untuk.Anda.yan g.Ingin.Take.Over.KPR. 
Setelah take over pengambilan atau cara pembayaran yang dilakukan mengikuti bagan dari perhitungan KUR Mikro dari bank BRI KCP Parepare. Ketentuan dan syarat beralaku setalah nasabah dinyatakan take over pada bank BRI Parepare yang mana ketentuan tersebut ditanda tangani oleh nasabah dan pihak bank dalam sebuah klausul perjanjian akad take over, ketentuan bayar sesuai ketentuan yang berlau. Rincian tabel pembayaran sebagai berikut

Tabel Pembiyaan BRI

\begin{tabular}{|c|c|}
\hline Jumlah Pinjaman & Suku Bunga \\
\hline Rp500 juta - 5 milyar & $9,75 \%$ Per Tahun \\
\hline Rp500 juta - 5 milyar & $10,25 \%$ Per Tahun \\
\hline Rp500 juta - 5 milyar & $13,00 \%$ Per Tahun \\
\hline
\end{tabular}

Sumber: Tabel pembiyaan BRI ${ }^{10}$

Tabel Pngsuran KUR Mikro 2018

\begin{tabular}{|c|c|c|c|c|c|c|c|}
\hline \multirow[t]{5}{*}{$\overline{\mathrm{NO}}$} & \multirow[t]{2}{*}{ SB EFEKTIF } & \multicolumn{6}{|c|}{$7.0000 \%$} \\
\hline & & $0.5833 \%$ & $0.5833 \%$ & $0,5833 \%$ & $0,5833 \%$ & $0,5833 \%$ & $0,5833 \%$ \\
\hline & $\begin{array}{l}\text { SB } \\
\text { FLATE/BULAN }\end{array}$ & $0.321 \%$ & $0.314 \%$ & $0.311 \%$ & $0.310 \%$ & $0.313 \%$ & $0,315 \%$ \\
\hline & PLAFOND & \multicolumn{6}{|c|}{ JANGKA WAKTU } \\
\hline & & 12 Bulan & 18 Bulan & 24 Bulan & 36 Bulan & 48 Bulan & 60 Bulan \\
\hline 1 & 5.000 .000 & 432,700 & 293,500 & 223,900 & 154,400 & 119,800 & 99,100 \\
\hline 2 & 6.000 .000 & 519,200 & 223,900 & 268,700 & 185,300 & 143,700 & 118,900 \\
\hline 3 & 7.000 .000 & 605,700 & 352,200 & 313,500 & 216,200 & 167,700 & 138,700 \\
\hline 4 & 8.000 .000 & 692,300 & 410,800 & 358,200 & 247,100 & 191,600 & 158,500 \\
\hline 5 & 9.000 .000 & $\overline{778,800}$ & 469,500 & 403,000 & 277,900 & 215,600 & 178,300 \\
\hline 6 & 10.000 .000 & 865,300 & 528,200 & 447,800 & 308,800 & 239,500 & 198,100 \\
\hline 7 & 11.000 .000 & 951,800 & 645,600 & 492,500 & 339,700 & 263,500 & 217,900 \\
\hline 8 & 12.000 .000 & $1,038,400$ & 704,300 & 537,300 & 370,600 & 287,400 & 237,700 \\
\hline 9 & 13.000 .000 & $1,124,900$ & 763,000 & 582,100 & 401,500 & 311,400 & 257,700 \\
\hline 10 & 14.000 .000 & $1,211,400$ & 821,600 & 626,900 & 432,300 & 335.300 & 277,700 \\
\hline 11 & 15.000 .000 & $1,298,000$ & 880,300 & 671,600 & 463,200 & 359,200 & 297,100 \\
\hline 12 & 16.000 .000 & $1,384,500$ & 939,000 & 716,400 & 494,100 & 383,200 & 316,900 \\
\hline
\end{tabular}

${ }^{10}$ Tabel Pembiyaan BRI 
Zulfhaidz Husain, Muhammad Kamal Zubair, Damira

\begin{tabular}{|l|r|r|r|r|r|r|r|}
\hline 13 & 17.000 .000 & $1,471,000$ & 997,700 & 761,200 & 525,000 & 407,100 & 336,700 \\
\hline 14 & 18.000 .000 & $1,557,500$ & $1,056,400$ & 806,000 & 555,800 & 431,100 & 356,500 \\
\hline 15 & 19.000 .000 & $1,644,100$ & 1,115100 & 850,700 & 586,700 & 455,500 & 376,300 \\
\hline 16 & 20.000 .000 & $1,730,600$ & $1,173,700$ & 895,500 & 617,600 & 479,000 & 396,100 \\
\hline 17 & 21.000 .000 & $1,817,100$ & $1,232,400$ & 940,300 & 648,500 & 502,900 & 415,900 \\
\hline 18 & 22.000 .000 & $1,903,600$ & $1,291,100$ & 985,000 & 679,300 & 526,900 & 435,700 \\
\hline 19 & 23.000 .000 & $1,990,200$ & $1,394,800$ & $1,029,800$ & 710,200 & 550,800 & 455,500 \\
\hline 20 & 24.000 .000 & $2,076,700$ & $1,408,500$ & $1,074,600$ & 741,100 & 574,800 & 475,300 \\
\hline 21 & 25.000 .000 & $2,163,200$ & $1,467,200$ & $1,119,400$ & 772,000 & 589,700 & 495,100 \\
\hline
\end{tabular}

Setelah calon nasabah merasa mantap akan melakukan take over ,nasabah dibawah dan dibimbingan oleh petugas bank BRI dalam hal ini marketing atau matri yang akan melakukan pengisian foam aplikasi permohonan untuk take over. Pada umumnya foam tersebut berisi tentang data pribadi, data pekerjaan, data suami istri, data penghasilan, pembiayaan / pinjaman lain, data kekayaan, data simpanan rekening di bank dan data agunan. pada pengurusan dokumen-dokumen dari bank sebelum take over,

Setelah aplikasi diisi dan ditandatangani oleh calon nasabah, kemudian diserahkan kembali kepada petugas bank dan petugas bank yang akan melakukan berbagai analisa atas permohonan pembiayaan dan take over yang akan dilakukan tersebut. Untuk beberapa kasus nasabah akan diberikan perlakuan khusus ketika mengisi aplikasi ini dimana nasabah akan diberitahukan informasi secepatnya dan konfirmasi mengenai pembiyaan yang nasabah gunakan lalu. ${ }^{12}$

Setelah foam aplikasi diisi nasabah akan melaukan wawancara kepada nasabah dimana wawancara yang dilakukan ini untuk mengetahui lebih rinci tentang Nasabah yang akan melakukan take over ini..Sebagai awal dari tahap analisa, petugas bank melakukan wawancara untukmencari kebenaran data di dalam aplikasi permohonan pembiayaan. Selanjutnya dilakukan pemeriksaan ke tempat calon nasabah untuk meneliti secara fisik kebenaran data permohonan pembiayaan, pemeriksaan ini pada dasarnya sebagai cara formal yang dilakukan bank, akan tetapi kebanyakan pegawai bank sebelumnya telah melakukan pemeriksaan sebelum nasabah ke bank untuk melakukan pengisian foam aplikasi.

Analisa yang dilakukan pegawai bank sebelumnya sudah dilakukan, ini bertujuan untuk mengefisienkan waktu agar waktu pengurusan yang akan ditempuh nasabah lebih bisa diminimaliris supaya tidak terkendala pada saat pengurusan dokumen-dokumen selanjutnya. Bank BRI melukan pendekatan secara kekeluargaan guna membuat nasabah lebih nyaman dalam

${ }^{11 B R I ~ U n i t ~ H a s a n u d d i n ~ P a r e p a r e, ~ T a b e l ~ A n g s u r a n ~ K U R, ~} 2018$.

${ }^{12}$ Muin, (Kepala Unit), Karyawan PT. BRI Unit Hasanuddin Parepare, Wawancara, tanggal 18 Juli 2018 di Parepare. 
melakukan proses tersebut, selain itu bebrapa faktor analisa yang harus diperhatikan oleh pegawai bank juga turut menjadi bagian penting dari proses analisa ini yang dimana proses tersebut menganalisa beberapa poin yaitu ;

\section{a. BI Checking}

BI checkingini bertujuan untuk mengetahui riwayat transaksi perbankan yang telah dilakukan oleh nasabah yang dimana BI cheking akan memberikan informasi pada bank tentang nasabah serta rekaman-rekaman nasabah yang telah menggunakan jasa perbankan apa saja dan BI cheking ini juga dapat mengetahui apakah nasabah pernah melakukan macet kredit ataupun hal-hal yang dapat merugikan bank

b. Kemampuan Bayar

Hal ini juga menjadi bahan analisa bank bagaimna kemampuan bayar calon nasabah kemudian bagaimana prospek usahanyanya kedepannya, penghasilan serta faktor-faktor finansial lainnya, kemudian seberapa besar keyakinan calon nasabah akan kemampuan bayarnya juga menjadi analisis penting.

c. Kondisi

Kondisi yang menjadi bahan analisis oleh pihak bank adalah dimana peluang terjadinya resiko macet kredit pada masa yang akan datang kemepuan bayar serta asset dari calon nasabah juga menjadi analisis kemudian, kebijakan dari pemerintah serta apabila nasabah adalah karyawan ataupun pegawai bagaimna kelangsungan pendapatannya guna memenuhi angsuran serta kehidupan sosial nasabah

d. Jaminan

Maksud dari jaminan disini adalah analisis yang dilakukan bank mengacu pada nasabah harus mampu meng-cover bisnisnya analisa yang dilakukan ini mengacu pada menganalisis kepemilikan jaminan yang diserahkan apakah sesuai dengan standar yang ada pada bank dan mampu menutupi kerugian dikemudian hari kemeudian mengukur dan memperkirakan stabilitas harga jaminan dimaksud serta memperhatikan kemampuan untuk dijadikan uang dalam waktu relatif singkat tanpa harus mengurangi nilainya, memperhatikan pengikatannya sehingga secara legal bank dapat dilindungi, rasio jaminan terhadap jumlah pembiayaan serta pihak bank juga menganalisa marketabilitas jaminan.

Setelah melukan prosedur analisa tersebut diatas bank akan memutuskan take over dapat dilakukan atau diterima ataupun ditolak karena baberapa unsur yang biasanya dinilai oleh bank tidak dapat melakukan akad atau dengan kata lain nasabah tidak memenuhi syarat untuk melaukan take over.

Pada bank BRI semua prosedur tersebut diatas adalah standar operasional yang harus diterapkan, meskipun demikian tidak menutup kemungkinan bank melaukan dengan cara yang lebih efektif tergantung lingkungan tempat tinggal serta kondisi masyarakat sekitar yang akan menggunakan jas dari bank BRI semua bertujuan untuk memberikan pelayanan yang maksimal pada nasabhnya agar lebih efisien dan lebih fleksibel. ${ }^{13}$

Setelah dilakukan beberapa proses diatas dan setelah dianalisa oleh pihak bank BRI. Calon debitur akan dipanggil oleh pihak bank, jika setuju dengan persyaratan yang termuat dalam akad tertulis oleh pihak bank, maka akan dilanjutkan dengan pengikatan pembiayaan dan agunan. Pencairan Pembiayaan. Setelah dilakukan pengikatan / perjanjian pembiayaan, selanjutnya adalah 
pencairan dana. Pencairan dana ini dilakukan melalui rekening nasabah. Jika nasabah belum mempunyai rekening pada bank BRI, maka nasabah diharuskan membuka rekening terlebih dahulu.Setelah melakukan pengikatan jaminan maka debitur dengan didampingi marketing menuju ke kreditur awal untuk melakukan pelunasan dengan dana yang diperoleh dari pihak ketiga.

Apabila pelunasan telah dilakukan, maka nasabah wajib meminta slip tanda pelunasan serta asli bukti kepemilikan jaminan ini untuk selanjutnya dapat dibebani Hak Tanggungan dengan terlebih dahulu dilakukan roya atas nama kreditur awal agar buktu dari pelunasan dapat disimpan sebagai bukti pelunasan untuk nasabah. Akibat hukum dari proses peralihan kredit tersebut adalah berakhirnya hubungan hukum antara kreditur awal dengan debitur. Objek jaminan yang akan dijaminkan harus dilakukan roya terlebih dahulu dan kemudian baru dibebani Hak Tanggungan. Akta Pembebanan Hak Tanggungan tidak dapat langsung ditandatangani antara kreditur dan debitur dikarenakan asli jaminan belum berada di tangan notaris. Hal yang dilakukan pada saat pengikatan jaminan didahului dengan penandatanganan Surat Kuasa Membebankan Hak Tanggungan untuk kemudian menjadi dasar dalam penandatanganan Akta Pembebanan Hak tanggungan ${ }^{14}$.

Biaya proses pada bank BRI Parepare adalah senilai paling tinggi Rp.250.000 ini termasuk biaya yang dikeluarkan pada nasabah dalam suatu proses transaksi tetapi pada dasarnya proses tersebut dilihat dari jenis produk apa yang nasabah pakai dan bagaimana tahapan kepengurusannya biasanya biaya tersebut hanya menggunakan sebgaian dari biaya maksimal proses tersebut diatas, dimana biaya proses atau biasa diebut juga dengan biaya adminstrasi yang digunakan untuk proses take over adalah ketemtuan ditinjau dan ditentukan sendiri oleh pihak bank terkait yaitu pihak bank dan biaya tersebut ber-variatif dan diusahakan seoptimal mungkin untuk mengurangi biaya yang akan dikeluarkan nasabah hingga selesai melaksakan peroes take over.

\section{Faktor yang mempengaruhi Take Over pada Bank Negara Indonesia Syariah}

Keinginan mealaukakn pemindahan pembayaran atau Take Over tidak serta merta timbul begitu saja akan tetapi ada bebarapa faktor yang telah dianalisis oleh pihak bank BNI syariah yang menyebabkan nasabah memlih untuk memindahkan pembayaran mereka atau menggunakan Jasa dari Bank BNI syariah diantaranya ${ }^{15}$

Faktor pertama, keinginan nasabah dalam melakukan transaksi pembiayaan dalam bentuk syariah.

Sudah sejak lama umat Islam Indonesia menginginkan sistem perekonomian yang berbasis nilainilai dan prinsip syariah (Islamic economic system) untuk dapat diterapkan dalam segenap aspek kehidupan bisnis dan transaksi umat. Keinginan ini didasari oleh suatu kesadaran untuk menerapkan Islam secara utuh dan total. Adapun dasar hukum dari penjelasan tersebut adalah: Q.S. Al-Imron ayat 3:130 Larangan Memakan Riba:

\section{kredit.html Parepare}

${ }^{14}$ Kajian Hukum Take Over Kredit, http:/ / bankingcentre.blogspot.com/2015/02/kajian-hukum-take-over-

${ }^{15}$ Sutoyo , (Kepala Cabang), Karyawan PT. BNI Syariah Mikro KC Parepae, Wawancara, tanggal 21 Juni 2018 di 
Hai orang-orang yang beriman, janganlah kamu memakan Riba dengan berlipat ganda dan bertakwalah kamu kepada Allah supaya kamu mendapat keberuntungan. ${ }^{16}$

KPR yang ditawarkan oleh bank BNI syariah berbeda dengan KPR yang ditawarkan oleh bank konvensional. Perbedaan mendasarnya terdapat pada akadnya. Pada KPR di bank syariah, akad yang digunakan mengacu pada prinsip jual-beli yang imbalan keuntungannya berupa margin penjualan. Sedangkan, KPR yang dimiliki oleh bank konvensional menggunakan akad pinjaman dengan bunga sebagai instrumen dalam penentuan keuntungannya, kemudian alasanyang sangat mendominasi nasabah dalam melakukan take over ke Bank BNI syariah adalah karena mereka menginginkan suatu transaksi yang berbasis syariah sesuai dengan tuntuntan Islam.

Faktor kedua, untuk mendapatkan fresh money atau dana segar. Sudah menjadi sebuah rahasia umum jika seseorang yang ingin melakukan take over dari satu bank ke bank yang lainnya adalah agar mendapatkan kucuran dana segar untuk menambah modal dalam pembiayaan atau modal bisnisnya. Sebagai mana dijelaskan dalam Firman Allah SWT, dalam QS. Al-Maidah 5:1

Terjemahnya:

Hai orang-orang yang beriman, penuhilah aqad-aqad itu. Dihalalkan bagimu binatang ternak, kecuali yang akan dibacakan kepadamu. (yang demikian itu) dengan tidak menghalalkan berburu ketika kamu sedang mengerjakan haji. Sesungguhnya Allah menetapkan hukumhukum menurut yang dikehendaki-Nya. ${ }^{17}$

Keberadaan take over ini dilihat dari segi manfaatnya sebagai penambah dana segar lebih banyak digunakan dalam bentuk pembiayaan modal kerja ataupun pembiayaan konsumtif KPR. Karena hal ini akan sangat membantu para pengguna dana tersebut dalam meningkatkan pinjaman atau pembiayaannya sehingga dengan adanya fresh money tersebut akan sangat memberikan dampak yang positif dalam kegiatan usaha mereka, ataupun untuk menambah biaya untuk renovasi rumah.

Faktor ketiga yaitu pembayaran angsuran dengan sistem fixed atau tetap. Sistem yang dianut oleh perbankan syariah pada pembayaran angsuran dalam pembiayaan menggunakan jenis flat atau fixed merupakan angsuran pembiayaan tetap. Seperti yang kita ketahui bahwa dalam pembayaran cicilan kredit terbagi menjadi tiga macam, yaitu: Flat Rate atau fix atau tetap, Sliding Rate atau efektif atau menurun dan yang terakhir Floating Rate atau anuitas atau mengambang. Maka diantara ketiga jenis pembayaran angsuran tersebut yang dibenarkan dalam Islam adalah yang pertama, yaitu menggunakan sistem FlatRate yang mana pembayaran cicilannya tidak mengalami kenaikan yang tidak beraturan sehingga dapat menimbulkan Gharar dalam muamalah tersebut namun selalu tetap dari bulan pertama hingga akhir. Karena metode ini tidak bergantung pada kenaikan tingkat suku bunga, sehingga akan mengurangi beban nasabah dalam melunasi angsurannya. Faktor ini sangat berkaitan erat dengan salah satu faktor yang telah saya uraikan diatas yaitu pada faktor yang pertama. Karena salah satu alasan nasabah dalam melakukan take over adalah menginginkan suatu transaksi perbankan dalam bentuk syariah atau bermuamalah sesuai dengan tuntunan dari syariat Islam.

\footnotetext{
16 Al Quran, Q.S Al-Imron 3:130

${ }^{17}$ Al Quran, Q.S Al-Maidah 5:1
} 
Faktor keempat, perbedaan margin dari bank syariah dengan bank konvensional. Margin dalam pembiayaan di Bank BRI Syariah merupakan keuntungan bank yang diawali pada murabahah atau jual beli. Dalam menetapkan besaran margin KPR ditentukan oleh komite kantor pusat dan Bank BNI Syariah menetapkan nilai juga tergantung pada setiap segmentasi, misalnya besaran margin KPR iB untuk 10 tahun adalah 16,25\%. Biasanya yang menjadi patokannya adalah harga pasar, tingkat suku bunga Bank Indonesia, manajemen risiko setiap bank, biaya operasional bank dan lain sebagainya. Antara bank syariah terjadi perbedaan dalam menetapkan margin pembiayaan. Bisa jadi bank syariah A marginnya lebih tinggi dibanding dengan margin yang ditetapkan oleh bank syariah B, atau sebaliknya. Disini peran nasabah dituntut untuk pro aktif mencari informasi perkembangan margin antar bank syariah. Sehingga, akhirnya nasabah itu dapat menetapkan kalau margin KPR suatu bank syariah tergolong rendah. Dan ini akan menguntungkan bagi nasabah. Karena pada dasarnya setiap nasabah menginginkan suatu yang lebih menguntungkan bagi mereka.

Faktor kelima, pemberian plafond yang rendah oleh bank konvensional. Plafond adalah jumlah nilai yang dibiayai pada awal akad. Jika bank konvensional memberikan plafond yang rendah, maka nasabah akan kesulitan untuk memutar kembali modalnya kerjanya. Dalam keadaan inilah Bank BNI Syariah berani memberikan plafond yang lebih tinggi lagi untuk menarik perhatian si nasabah tersebut. Hal ini mempengaruhi keinginan nasabah dalam melakukan take over ke bank syariah karena pada dasarnya nasabah dewasa ini sudah lebih "pintar" dalam menilai pembiayaan dari banyak perbankan, baik itu yang bergerak dalam bidang syariah maupun konvensional. Sehingga lembaga keuangan seperti perbankan harus pandai dalam mengatasi hal ini, berupa pemberian plafond kepada calon nasabah.

Pada kenyataannya nasabah akan lebih memilih perbankan yang berani memberikan plafond yang lebih banyak daripada bank sebelumnya. Jumlah nilai yang dibiayai pada awal akad tentu saja berbeda antara satu nasabah dengan nasabah yang lainnya, hal ini akan menjadi pertimbangan yang sangat menentukan bagi bank syariah dalam mengambil kebijakan untuk menerima atau menolak suatu pembiayaan. Dalam kondisi inilah yang membuat Bank BNI syariah beranimenggelontorkan dana yang besar hanya untuk seorang nasabah, karena Bank BNISyariah melihat perputaran usahanya bagus, jaminan yang diberikan masih bisa mengcover pembiayaan, kemudian nasabah tersebut juga mempunyai reputasi yang baik pada dunia perbankan, tidak termasuk nasabah blacklist, track recordnya selalu baik dan pembiayaan yang diajukannya juga lancar.

Faktor keenam, adanya hubungan emosional antara nasabah dengan marketing suatu bank, karena setiap marketing punya nasabah yang dimaintanance dan relasi mereka dari dulu, sehingga kemanapun marketing itu bertugas, maka si nasabah akan mengikutinya. Dalam kondisi yang seperti ini, maka nasabah tersebut bisa dikatakan sebagai nasabah yang loyal, integritas dan kredibilitas nasabah tersebut tidak diragukan lagi.

\section{Faktor yang mempengaruhi Take Over pada Bank BRI KCP Parepare (Unit Hasanuddin)}


Pada bank BRI KCP Papare dalam sistem Take Over, nasabah diberikan pelayan secara prima dari awal pemindahan pembayaran, pada saat pembiyaan berlangsung dan pada saat pelunasan dilakukan, kemudian adapun faktor yang menjadi daya tarik tarik nasabah menngunakan jasa bank BRI dalam melakukan Take Over diantaranya adalah ;

Faktor pertama, suku bunga pada suatu bank menjadi pertimbangan tersendiri pada nasabah ketika ingin menggunakan jasa lembaga keuangan khususnya lembaga perbankan. Bank BRI KCP Parepare didalam pembiyaan take over itu sendiri menetapkan suku bunga yang mecapai 0,75\% dimana suku bungan tersebut yang turut menjadi salah satu faktor utama nasabah melakukan take over,suku bunga yang ringan ini sendiri adalah satu salah layanan yang diberikan kepada nasabah agar dapat memberi keuntungan lebih pada nasabah yang menginginkan angsuran yang lebih terjangkau.

Faktor kedua, Tanggungan yang berupa asuransi tidak dibayarkan oleh nasabah melaikan ditanggung oleh pihak Bank BRI. Dalam pembiyaan take over nasabah yang akan melakukan pemindahan pembayaran harus terdaftar dalam asuransi ini bertujuan untuk memindahkan resiko yang akan mungkin terjadi dikemudian hari. Biaya asuransi sejatinya adalah biaya yang dibayarkan untuk memastikan amannya suatu keadaan dan tindakan untuk mencegah resiko, akan tetapi nasabah yang ingin melakukan take over biasanya enggan melakukan pemindahan pembyaran dikarena harus menanggung biaya asuransi itu sendiri. Pada bank BRI KCP Parepare biaya yang dibayarkan untuk asuransi sudah tidak ditanggung oleh nasabah, inilah yang menjadi salah satu faktor nasabah ingin melakukan pemindahan pembayaran atau take over karena biaya asuransi yang berupa asuransi kesehatan dan kebakaran telah ditanggun oleh pihak bank BRI dengan demikian nasabah bisa mengurangi biaya yang mereka keluarkan.

Faktor ketiga, Suku bungan yang digunakan adalah suku bunga tetap atau Fixed and Floating atau flat. Suku bunga adalah dasar utama dalam penentuan suatu pembiyaan, sebelum melakukan pembiyaan atau melakukan take over nasabah harus mempelajari terlebih dahulu tentang kemungkinan berubahnya suku bunga. Dengan adanya suku bunga yang tetap nasabah akan lebih mudah mudah menghitung pembiyaan yang kan mereka lakukan, suku bunga tetap atau Fixed and Floatinginilah yang digunak oleh bank BRI dalam pembiyaan take overdan menjadi salh satu faktor nasabah memilih menggunakan pembiyaan dan jasa bank BRI dikarena angsuran yang dibayarkan jumlahnya tidak akan berubah atau jumlah tetap dari awal pembyaran sampai dengan selesainya pembiyaan.

Faktor keempat, Tenor yang dapat disesuaikan sesuai dengan kemampuan bayar nasabah. Dalam analis nasabah yang telah dibahas sebelumnya penghasilan nasabah adalah salah satu poin penting yang harus bank analisis dan dilakukan pelaporan tentang penghasilan atau gaji nasabah. Penghasilan tersebutlah yang akan menjadi menjadi dasar penetapan tenor dalam pembiyayaan. Pada sistem perbankan jumlah angsuran yang harus dibayarkan perbulannya telah ditentukan oleh ketentuan perbankan itu sendiri akan tetapi pada bank BRI KCP Parepare nasabah akan diberikan layanan oleh mantri BRI untuk menetukan tenor mana yang akan mereka gunakan yang dalm penetuan tersebut nasabah akan diberikan kemudahan untuk menetukan seberpa besar angsuran yang harus dibayarkan dan seberpa besar nominal angsuran yang harus nasabah bayarkan dan berapa lama tenor yang akan nasabah gunakan sesuai dengan kenyamanan dan 
kempuan bayar nasabah agar pembiyaan dapat berjalan dengan lancar dari awal pembiyaan sampai dengan selesainya pembiyaan yang dilakukan oleh nasabah.

Faktor kelima, Adanya hubungan emosional yang terjalin antara pihak marketing (mantri BRI) dengan nasabah. Hungan yang terjalin antara nasabah dan pihak bank BRI bukan hanya sebatas nasabah yang menggunakan lembaga itu sendiri akan tetapi pihak bank BRI berusaha memberikan pelayan prima kepada nasabah dengan melakukan pendekatan-pendekatan guna menjalin hubungan emosional kepada nasabah agar kenyamanan serta kepercayaan biasa terus terjaga antara nasabah dan pihak bank BRI ini juga yang menjadi salah satu faktor nasabah menggunakan pembiyaan dan jasa bank BRI, hubungan emosional tersebut biasanya diterapkan kepada nasabah dengan melakukan pelyanan lebih seperti, memungkinkan nasabah diberi pelayan berpa angsuran pembayaran dapat dijemput langsung oleh Marketing bank BRI tanpa harus ke bank.

Faktor keenam, Apabila nasabah melakukan pelunaan diawal tidak akan dikenakan pinalty melaikan nasabah akan diberikan potongan pelunasan diawal berupa Discount,pinalty sangat erat kaitannya dengan take over dan angsuran berjalan pada suatu pembiyaan. Pinalty dianggap nasabah adalah salah satu persyaratan dalam instrumen pembiyaan yang merugikan bagi mereka, hal ini yang biasanya menjadi salah satu bahan pertimbangan utama pada nasabah dalam menetukan pembiyaan yang akan nasabah gunakan. Pada bank BRI pinalty tidak akan dikenakan kepada nasabah yang akan melakukan pelunasan pembiyaannya diawal pembiyaan, melainkan pada saat nasabah ingin melakukan pelunasan diawal nasabah akan diberikan potongan pembayaran sesuai dengan ketentuan bank BRI pada pembiyaan yang telah berjalan satu tahun. Hal inilah yang menjadi salah satu satu faktor yang menyebabkan nasabah melakukan take over pada bank BRI karena dianggap sangat menguntungkan pada nasabah terutama pada nasabah yang mendapatkan dana lebih bisa segera melunasi pembayarannya tanpa harus memifirkan biaya pinalty yang ada.

\section{Perbedaan System Take Over BNI Syariah Mikro KC Parepare dan BRI KCP Parepare (Unit Hasanuddin)}

Dalam sistem take over antara BNI Syariah Mikro KC Parepare dan BRI KCP Parepare (Unit Hasanuddin) tidak terjadi perbedaan mendasar pada keduanya akan tetapi klasifikasi antara beberapa item serta prosedur yang membedakan berlangsungnya take over sampai pada pelunasan atau selesainya kegiatan take over antara lain ;

\section{a. Akad Pembiyaan Take Over}

Pada bank BNI Syariah Mikro KC Parepare adalah berpedoman pada fatwa Dewan Syariah nasional Nomor : 31/DSN-MUI/VI/2002 tentang pengalihan utang. Take over dilakukan dengan membeli sebagian asset yang telah dibeli oleh nasabah pembiayaan take over, harga asset yang dibeli oleh pihak BNI Syariah adalah sebesar bagian asset yang senilai dengan utang (sisa cicilan nasabah kepada bank yang lama). Nasabah bertindak atas nama BNI syariah melunasi sisa harga asset yang telah diambil alih oleh BNI Syariah, kemudian Setelah sisa asset tersebut dimiliki oleh BNI Syari ah, BNI Syariah menjual secara Murabahah bagian asset yang menjadi miliknya tersebut kepada nasabah dengan pembayaran secara cicilan sebesar harga sisa cicilan nasabah pada bank yang lama 
ditambah dengan margin keuntungan bank yang telah disepakati bersama.

Pada BRI KCP Parepare (Unit Hasanuddin) pembiyaan take over sesuai dengan ketentuan bank BRI dimana dengan memindahkan pembayaran nasabah sesuai tenor yang telah ditentukan setelah nasabah menyelesaikan sangkutan atau tanggungannya pada pembiyaan sebelumnya setelah take over pengambilan atau cara pembayaran yang dilakukan mengikuti bagan dari perhitungan KUR Mikro dari bank BRI KCP Parepare. Ketentuan dan syarat berlaku setelah nasabah dinyatakan take over pada bank BRI Parepare yang mana ketentuan tersebut ditanda tangani oleh nasabah dan pihak bank dalam sebuah klausul perjanjian akad take over kepada pembeli atau nasabah. Hubungan yang terjadi antara keduanya adalah hubungan mitra antara penjual dan pembeli bukan atas hubungan kreditor dan debitor. Jadi terdapat hubungan yang setara antara keduanya.

\section{b. Jenis Pembiayaan}

Jenis pembiyaan ini dibedakan dengan masing-masing produk yang dimliki dan ditawarkanoleh Bank BNI syariah Mikro KC Parepare dan Bank BRI KCP Parepare (Unit Hasanuddin) yang dimana produk tersebut menjadi beberapa produk anatara lain :

1) Pembiyaan BNI Syariah Mikro KC Parepare

Jenis pembiyaan yang ditawarkan ole bank BNI syariah lebih banyak pada jenis pembiyaan kepemilikan KPR Pembiayaan KPR (Ke-pemilikan Perumahan Rakyat) pada bank BNI syariah terdiri dari dua jenis diantaranya:

a) Pembiayaan kepemilikan rumah bersubsidi yang diperuntukkan kepada masyarakat berpenghasilan menengah kebawah dalam rangka memenuhi kebutuhan perumahan yang ingin dimiliki. Pembiayaan KPR bersubsidi ini diatur tersendiri oleh Pemerintah, sehingga tidak setiap masyarakat yang mengajukan kredit dapat diberikan fasilitas ini. Secara umum batasan yang ditetapkan oleh pemerintah dalam memberikan subsidi adalah penghasilan pemohon dan maksimum kredit yang diberikan. Tipe rumah yang diperbolehkan adalah rumah dengan tipe 36. DP atau uang muka untuk pembiayaan KPR bersubsidi ini bisa dengan hanya menyediakan uang sebesar 5\% dari jumlah harga beli rumah.

b)Kedua, adalah pembiayaan kepemilikan rumah non-subsidi yang diperuntukkan bagi seluruh masyarakat. Ketentuan KPR ditetapkan oleh bank,sehingga penentuan besarnya kredit maupun nisbah bagi hasil dilakukan sesuaikebijakan bank BNI Syariah, yaitu persyaratan-persyaratan pengajuan telah diungkapkan di atas. Untuk pembiayaan kepemilikan rumah non-subsidi ini, bank BNI syariah mengambil keuntungan lebih besar dari KPR bersubsidi dan uang muka atau DP-nya 30\% dari harga beli rumah yang dilakukan oleh bank ke Developer.

2) Jenis Pembiyaan pada Bank BRI KCP Parepare (Unit Hasanuddin) Pada bank BRI Pembiyaan KPR menggunakan jenis KPR suku bunga flat atau biasa juga disebut dengan fixed and Floating yang pada suku bungan flat ini jumlah ansguran yang harus dibayarkan oleh nasbahnya tidak berubah atau tetap dari awal angsuran sampai dengan selesainya angsuran dengan jenis pembiayaan take over berupa:

a) Take Over KPR

b) Take Over Kendaraan Bermotor 


\section{c. Biaya Pelunasan Awal, Ketentuan Uang Muka Nasabah, Pinalty}

1) Biaya Pelunasan Awal, Ketentuan Uang Muka Nasabah , Pinalty pada Bank BNI Syariah Mikro KC Parepae

Pada Bank BNI syariah ketentuan uang muka nasabah Pelunasan diawal yang dilakukan pada BNI Syariah tetap mengacu pada peraturan fatwah DSN-MUI dalam akan Murabahah. Dalam akad murabahah, LKS diperbolehkan untuk memita uang muka, kemudian besar uang muka ditentukan berdasarkan kesepakatan, jika nasabah membatalkan akad, nasabah harus memberikan ganti rugi kepada LKS dari uang muka tersebut. Apabila uang muka lebih kecil dari kerugian maka LKS dapat meminta tambahan kepada nasabah, Jika uang muka lebih besar dari kerugian, maka LKS harus mengembalikan kelebihannya kepada nasabah.

Pinalty juga tidak terdapat pada bank syariah khususnya Bank BNI syariah karena sudah disepakati diawal meskipun nasabah melakukan pelunasan dimuka yang dimana harga jual beli adalah suatu jumlah yang disepakati oleh kedua belah pihak drnagan akad Murabahah. Jika dalam murabahah LKS mendapat diskon dari supplier, maka diskon tersebut adalah hak nasabah, diskonsetelah akad, maka pembagian diskon sesuai perjanjian persetujuan dalam akad kemudian pembagian diskon setelah akad hendaklah diperjanjikan dan ditandatangani.

2) Biaya Pelunasan Awal, Ketentuan Uang Muka Nasabah, Pinalty pada Bank BRI KCP Parepare (Unit Hasanuddin)

Pada bank BRI iru sendiri didalam melakukan kegiatan pembiyaan segala bentuk dari rincian telah tertuang dalam akad perjanjian.Potongan penulasan dimuka Pada nasbah yang ingin segera menyelesaikan pembiyaannya atau angsurannya biasanya terdapat potongan pelunasan dimuka atau biasa juga disebut pinalty. Padabank BRI biaya pinalty tidak berlakukan apabila nasabah inigin melakukan pelunasan diawal. Nasabah yang sudah melakukan pembayaran selama satu tahun akan mendapatkan fasilitas berupa potongan harga bagi nasabah yang inigin melakukan pelunasan dimuka, potongan tersebut berupa discount yang berlaku sesuai dengan ketentuan pihak bank.

Pada saat melakukan take over segala sangkutan dari bank asal harus terselesaikan mualai dari angsuran pembiyaan serta dokumen-dokumen terkait akan teapi pada bank BRI biaya pinalty tidak dilakukan pada nasabah biaya. Pada bank BRI biaya pinalty tidak ada dalam pelunasan diawal. Pada bank BRI biasanya nasabah malah mendapat potongan atau discount pada saat melakukan pelunasan diawal18

\section{Kesimpulan}

Berdasarkan dari hasil penelitian dan pembahasan yang telah dijelaskan pada BAB IV, maka kesimpulanyang dapt ditarik adalah sebagai berikut ;

1. Pada prosedur pelaksanaa Take Over di kedua Bank yaitu Bank BNI Syariah KC Mikro Parepare dan Bank BRI KCP Parepare (Unit Hasanuddin), memiliki persamaan pada prosesmya yaitu, sebagai awal dari sistem pembiayaan take over, calon nasabah pembiayaan take over sebelum mengajukan permohonan pembiayaan terlebih dahulu berkonsultasi dengan pihak Bank, konsultasi ini dimaksudkan untuk mencari informasi mengenai pembiayaan take over baik berupa bagaimana sistem, syarat, maupun margin

${ }^{18}$ Fahmi Farid Hidayat, (Mantri), Karyawan PT. BRI Unit Hasanuddin Parepare, Wawancara, tanggal 18 Juli 2018 di Parepare. 
keuntungan maupun Nisabah bagi hasil seprti apa yang diambil oleh pihak Perbankan. Akan tetapiSistem take over dilakukan oleh Ban BNI Syariah Mikro KC Parepare adalah dengan membeli sebagian asset yang telah dibeli oleh nasabah pembiayaan take over, harga asset yang dibeli oleh pihak BNI Syariah adalah sebesar bagian asset yang senilai dengan utang (sisa cicilan nasabah kepada bank yang lama). Nasabah bertindak atas nama BNI syariah melunasi sisa harga asset yang telah diambil alih oleh BNI Syariahsedangkan, pada Bank BRI KCP Parepare Sistem take over Yang dilakukan adalah nasabah lebih dahulu melunasi atau menyelesaikan sangkutannya di bank pembiyaan sebelumnya kemudian setelah itu maka akan dilakukan akad pembiyaan Take Overse telah semua instrument dari ketentuan bank BRI telah terpenuhi.

2. Faktor yang mempengaruhi Take Over pada Bank BNI Syariah KC Mikro Parepare dan Bank BRI KCP Parepare (Unit Hasanuddin), memlilki beberapa persamaan diantaranya menjalin hubungan emosional antara pihak bank dan nasabah, kemudian nisbah bagi hasil yang akad perjanjiannya berupa pembayaran tetap sama dengan bunga flat yang ditawarkan oleh bank BRI akan tetapi bank BRI memberikan discount pada pelunasan awal yang dilakukan nasabah dan biaya asuransi untuk take over itu sendiri ditanggung oleh

pihak bank BRI, kemudian kecenderunganutama nasabah memilih bank BNI syariah karena akad yang dijalankan berupa akad syariah.

\section{Daftar Pustaka}

\section{Buku}

Zainal, Ahmad. Mengenal Lembaga Keungan Bank dan Non Bank. Jakarta:Akasara Pertama Pena, 2013.

Sutedi, Andrian. Perbankan Syariah. Bogor: Ghalia Indonesia, 2009.

Riza Salman, Kautsar. Akuntansi Perbankan Syariab: Berbasis PSAK Syariah. Jakarta: Akademia Pertama, 2014.

Yaya, Rizal. Moderenisasi jasa perbankan Indonesia Teori Dan Praktik Kontenporer. Jakarta: Salemba Empat, 2012.

Rivai, Veithzal \& Arviyan Arifin, Islamic Banking: Sebuah Teori, Konsep, Dan Aplikasi. Jakarta, PT Bumi Aksara, 2010.

\section{Wawancaara}

Muin, (Kepala Unit), Karyawan PT. BRI Unit Hasanuddin Parepare, Wawancara, tanggal 18 Juli 2018 di Parepare.

Fahmi Farid Hidayat, (Mantri), Karyawan PT. BRI Unit Hasanuddin Parepare, Wawancara, tanggal 18 Juli 2018 di Parepare.

\section{Website}

Kajian Hukum Take Over Kredit, http://bankingcentre.blogspot.com/2015/02/kajian-hukum-take-overkredit.html 
Zulfhaidz Husain, Muhammad Kamal Zubair, Damira

Sutoyo , (Kepala Cabang), Karyawan PT. BNI Syariah Mikro KC Parepae, Wawancara, tanggal 21 Juni 2018 di Parepare

Kompas,comhttps://properti.kompas.com/read/2014/01/31/1208428/Nih.Beberapa.Tawaran.untuk.Anda. yang.Ingin.Take.Over.KPR.

Liesti Yowati, Indahnya Belajar Akuntansi, (Akuntan-si.si.blogspot.co.id/2013/definisi-dan-mekanisme-takeover.hmtl?m=1).

\section{Dokumen Lain}

Fatwa DSN Nomor : 04/DSN-MUI/IV/2000 Tentang Murabahah

Tabel Pembiyaan BRI

BRI Unit Hasanuddin Parepare, Tabel Angsuran KUR, 2018. 